EPRA International Journal of Economic and Business Review-Peer Reviewed Journal Volume - 9, Issue -2, February 2021 | e-ISSN: 2347 - 9671| p- ISSN: 2349 - 0187

SJIF Impact Factor (2021): 8.302 || ISI Value: 1.433 || Journal DOI URL: https://doi.org/10.36713/epra2012

\title{
CORONA VIRUS, CHILD LABOUR AND IMPERFECT MARKET IN INDIA
}

\begin{tabular}{|c|c|}
${ }^{1}$ Dr. Ipsita Priyadarsini \\
Pattanaik
\end{tabular}$\quad \begin{gathered}\text { Research Scholar in Economics, } \\
\text { Fakir Mohan University, Balasore, Odisha }\end{gathered}$

ABSTRACT

Article DOI URL: $\underline{\text { https://doi.org/10.36713/epra6086 }}$

The objective of the study is to analyse impact of corona virus in child labour in India. Covid-19 pandemic has created a big challenge in front of the world and India its negative impact on the economy has also created the possibilities of an increase in child labour. One impact would be an increase in the number of child workers. Along with the health crisis, and the economic and labour market shock that the pandemic has generated, the vulnerability of millions to child labour is another issue that merits serious attention. Already, there are 152 million child labourers worldwide. Despite the prohibition of engagement of children below the age of 14 in all occupations, India alone is home to 10.1 million child labourers in the age group 5-14 years Census 2011. As per the Centre for Monitoring Indian Economy's (CMIE) weekly tracker survey, the impact of COVID-19 has already pushed the urban unemployment rate to $30.9 \%$ as on April 5, which was $8.21 \%$ on March 15 estimates show that about 400 million informal workers in India may not get back their livelihood status for a longer period in the near future

KEYWORDS:- Child labour, Covid-19, Health, Unemployment, Work

\section{INTRODUCTION}

Child labour is a very challenging issue in the world. It is a perennial problem in both developing and developed countries. It is shameful for the whole mankind where children are being abused by the society. Thousands of attempt has been taken at international as national level to eradicate or abolition of child labour, yet the magnitude has been increasing at an alarming rate, particularly in third world countries. It is a shocking fact that about 90 percent of child labourers is concentrated in the underdeveloped countries of the world. It is true that, child labour is a universal issue. But the proportion of child workers is different in different regions. In south Asia it is 5.4 percent but in Africa it is 4 percent only. In latrine America countries the child labour is only 2.6 percent. In total figure that ILO has estimated in 248 million of child labour which developing countries, India possesses the highest number of child labourers in the world.

Participation of children in work is not a new concept in modern age. It has happened in different forms in every society through the human history. Mendelievich has properly observed "To a greater or lesser extent, children in every type of human society have always taken part, and still do take part, in those economic activities which are necessary, if the group to which they belong is to survive". It has been pointed out in the report of the Committee on child labour also that child labour is 
not a new occurrence correlated to our age. It has occurred in one form or another in all historical times. As we see in the later parts of this thesis, employment of geographic, social, national and religious limits and has become an established practice in all countries. But, it is also similarly important to note that every working child does not organise to be a part of child labour, as child labour is related with the presence of certain features such as deficiency from school, unkindness, etc.

Bekombo analyses how in Africa, children are socialise themselves through their participation in the activities like hunting, fishing, construction and sale of produce in the market. In urban areas, they are generally employed as pesters, house servants, or washers and guards. Sometimes, they are also involved in trade in stolen market products and luxury contraband items like watches, electronic goods, clothes etc. In Asia, agriculture and the related activities involved a significant measurement of child workers in the rural areas. Children also provide an assisting hand to their families, which are involved in cottage industries, fishing, washing and retail trades. In Iran, Afghanistan, and Pakistan and in India, they work in carpet factories, while in Sri Lanka and India, in tea, coffee and rubber plantations and in Thailand, in factories, hotels, and street trades and sports grounds.

Hayes highlights that certain of the boys and girls also work as prostitutes in Thailand where goodlooking children are regularly sold to brothels. In Hong Kong, children are employed in light manufacturing and textile industries, domestic work, catering places and houses. In Latin America Countries, child labour is extensively focussed in agriculture and plantations in the rural areas and domestic services, street trade and services in the small scale industries, in the urban areas. Regularly such as employment is prepared by the adults, but sometimes minors are also able to find work without any adult provision e.g. in carrying provisions at the super market exit or at food fairs, in washing cars on the streets or in the parking lots. In Jamaica, parents repeatedly remove their children from school for small domestic or agriculture tasks because they reflect that one or two days of schooling is adequate for education.

The covid-19 pandemic has created a big challenge in front of the world and India. It's negative impact on the economy has also created the possibilities of an increase in child labour. The coronavirus pandemic is forcing India's children out of school and into farms and factories to work, worsening a child-labour problem that was already one of the terrible in the world. The International Labour Organisation reports that the economic and labour crisis, created by COVID-19, may see global unemployment increase by almost 25 million working poverty rates will increase significantly. With a prediction that there will be between 20.1 million and 25 million more people in working poverty than in the pre COVID-19 estimate. As governments order non-essential business to close, millions of people employed in the performance economy who for the most part are on precarious but the pandemic poses very real risks of backtracking. Positive trends may falter, and child labour may worsen, especially in places where it has remained resistant to change. These risks require urgent action to prevent and mitigate the tolls the pandemic takes on children and their families. Highlights recent years have seen significant progress in the fight against child labour.

The current COVID-19 pandemic, however, can potentially reverse the positive trends observed in several countries and further aggravate the problem in regions where child labour has been more resistant to policy and programme measures. Recent years have seen significant progress in the fight against child labour. The current pandemic, however, can potentially reverse the positive trends observed in several countries and further aggravate the problem in regions where child labour has been more resistant to policy and programme. Some of the initiatives include the Child Labour Prohibition and Regulation Act which is a piece of legislation that prohibits the engagement of children in certain employment mostly in dangerous conditions and regulates the conditions of work of children; the National Policy on Child Labour seeks to adopt a sequential approach with focus on rehabilitation of children working in hazardous occupations \& processes in the first instance; and the Ministry of Labour and employment function. The International Labour Organization (ILO), a Geneva-based UN agency, announced that child labour has decreased by 38 per cent in the last decade but warned that the raging Covid-19 pandemic has considerably worsened the situation with 152 million children still affected.

The differential impact of the COVID-19 pandemic on society needs to be acknowledged. While some of us are practising social distancing and exploring work from home options aggressively in the hope of a better tomorrow, there is a possibility that a substantial number of children would emerge as victims of such apparently positive measures. One impact would be an increase in the number of child workers. Along with the health crisis, and the economic and labour market shock that the pandemic has generated, the vulnerability of millions to child labour is another issue that merits serious attention. Already, there are 152 million child labourers worldwide. Despite the prohibition of engagement of children below the age of 14 in all occupations, India alone is home to 10.1 million child labourers in the age group 5-14 years Census 2011. If the state governments do not take immediate and accelerated efforts to address this issue, we are going to lose the battle of eliminating all forms of child labour 
by 2025, a commitment under the sustainable development goals (SDGs).

\section{REVIEW OF LITERATURE}

Dilip R. Khairnar (2017) in his study observed that in India the child labourers are in largest number. The root cause of this problem each due to poverty and social inequality in India. In this study Marathwada region has been selected to examine and identified the basic causes of child labour. It is revealed that, nearly $78.60 \%$ of child labourers are minor in the stage collection of 9-14 ages. The family income of $88 \%$ of families of child labour is limited to $1000-2000$ rupees per annum. It is also shocking that as well as $67 \%$ of minor workers are homeless, $44 \%$ of workers belong to diverted families. Only $35 \%$ of child labourers are living with their parents. The study also shows that $87 \%$ children are in nutritional deficiency $33 \%$ of child labourers are survived by taking only one meal a day. The situation of child labourers in worse who belong the family addicted to alcohol and Tabaco. Because of poor economic conditions of the family, $39 \%$ children are forced to work as a child labourer. The working hour of the child labour is more than 12hours, maximum of them are suffered from skin and infection diseases .About $79 \%$ of child labour are either illiterate or school dropouts. To present child labour in India, there are various provisions in the constitution of India and both central and state government has enacted a number of laws and acts. But due to lack of strong political will, poor implementing machineries and flexible clauses in the law, the problem of child labour persists in India.

Susmita Sengupta and Shovan Ghosh (2013) highlighted different steps and legislation formulated by the Government of India towards reduction of poverty. The constitution of India has guaranteed permitted and necessary education to every children below the stage of 14. This is due to social disparities of class, caste and gender for which a number of children are deprived from education in villages. The people below poverty line are engaging their children in different works to enhance the family income. Moreover, their study highlights the gap between policy decisions and its implementation to achieve the goal .It suggests some specific policies, the implementation of which will declined the rate of child labour. Child labour is a universal issue. Now due to industrialisation and globalisation, the matter of child labour is at its highest in organised and unorganised sectors, the child labour is justified in giving false age certificate. They are forced to work more than the prescribed hours of duly.

Sofya Krutikova (2009) mentioned that the major three determinants are (1) income, (2) family composition and (3) parent on preferences. Besides the author analyses the Yard Sticks like psychology and social abilities and nutritional level of the child labour. He has taken the case study of Andhra Pradesh and interview the children in the age group of 7-11 to find out the labour sensitiveness. According to him with the study the child worker in a house hold is more sensitiveness than a worker in urban Ares. The bargaining power of the labour also varies from place to place. The study also exposes the nutritional status regarding skill and ability of child labour in comparison to how much he works

Mridul Maheshwari Manjari Singh W.P (2008) stated that the topic of child labour in India, in a very alarming stage. It needs special attention of the decision makers to redress the problem for the formulation of an effective policies factors of child labour should be examined. In 35 states and union territories the author has examined these factors. In this study total population in urban and rural areas are examine and proved that the most important factors are education, fertility and participation. The economic variables differs from locality and to men to women.

Tripathy (1989) focussed on the child labour in the capital city of Bhubaneswar (Odisha). The knowledge found out that as many as more than zero child labourers are engaged in varieties works in the city. It is also provided that child labourers are mostly belong to the background tribal districts of Odisha. In those districts, most of the child labourers are engaged in agricultural sector. The study also reveals that, India is the only country where the complete of child labour are highest.

\section{CONSEQUENCES OF IMPERFECT LABOUR MARKET}

All over the world, the quantity and quality of employment is deteriorating rapidly because of COVID-19. The subsequent economic shock will increase both unemployment and underemployment. Besides the number of jobs, there is also the possibility of downward adjustment to wages, social security and working hours. The effect will be more on informal sector workers, including self-employed, casual and gig workers, and migrant workers who are more vulnerable to adverse labour market outcomes. Around $90 \%$ of India's workforce is in the informal sector. As per the Centre for Monitoring Indian Economy's (CMIE) weekly tracker survey, the impact of COVID-19 has already pushed the urban unemployment rate to $30.9 \%$ as on April 5, which was $8.21 \%$ on March 15 estimates show that about 400 million informal workers in India may not get back their livelihood status for a longer period in the near future. Without adequate credit or savings to withstand financial setbacks, and without adequate governmental support, these households will be left with no other option than putting their children in the workforce to aid survival. The children of farmers and agricultural labourers in India are at even greater risk. As government restrictions to movement and gatherings have been imposed during harvesting and marketing time, in 
the absence of helping hands, children will be the fullback option to assist parents in the fields.

\section{CHILD LABOUR AND COVID-19 CRISIS}

The situation will also be alarming for legally working children (15-18 years). The Child Labour (Prohibition and Regulation) Amendment Act, 2016, which prohibits the engagement of adolescent children in hazardous occupations and processes, slashed the list occupations considered hazardous from 83 to 3 mining, explosives, and occupations mentioned in the Factory Act. However, data shows children between 15-18 years engaged in hazardous work account for $62.8 \%$ of the India's child labour workforce, $10 \%$ of whom are engaged in family enterprises. Because of low production during COVID-19, recently, many of the state governments are in the process of extending working hours at factories from a maximum of 8 hours to 12 hours a day with a limited workforce. Such a provision, seen in the context of adolescent child workers, will mean more at lower wages, as children are the cheapest labour force.

\section{MORTALITY AND CHILD LABOUR}

As on Tuesday evening, the COVID-19 pandemic has infected over 25 lakh people in 185 countries, resulting in more than 1.7 lakh deaths. In India, around 19,000 COVID-19 cases have been identified and the death toll has crossed 600. This will inevitably leave many children without one or both parents or other caregivers. Orphaned children are particularly vulnerable to trafficking and other exploitation like forced begging, or child labour. In such families, there is also the likelihood of older children dropping out of school to support their younger siblings.

\section{CLOSURE OF SCHOOLS DURING COVID-19 AND INCREASE IN CHILD LABOUR}

As an immediate measure to stem the spread of the COVID-19 pandemic, governments around the world have shut down educational institutions. UNESCO estimates that as of April 20, $91.3 \%$ of total enrolled learners, that is 1.57 billion learners from 191 countries, were affected by school closures. The Government of India has also opted for a nationwide school closure. UNCESCO also estimates that around 32 crore learners are affected in India, of which 15.8 crore are female and 16.2 crore are male students. The bulk of these students are enrolled in primary and secondary schools $(86 \%)$, followed by tertiary $(10 \%)$ and pre-primary (4\%) level of education. As governments are obligated to respect the right to education of children, UNESCO has recommended that countries adopt a variety of hi-tech, low-tech and no tech solutions to assure the continuity of learning during this period.

Most of the focus has been on online learning platforms, even though nearly half of the world has no internet access. A similar scenario prevails in India. The Ministry of Human Resource Development (MHRD) has suggested that all schools should connect with their students through digital platforms to compensate for the loss of school hours. Therefore, a large number of children studying in public schools remain cut off from online education. The closure will disproportionately affect children who already experience barriers in accessing education, or who are at higher risk of exclusion. This includes children with disabilities, students in remote locations, children of migrant workers, or those whose families have lost income as a result of job loss or precarious employment.

\section{CONCLUSION}

The millions of children who will be victims of the COVID-19 pandemic need immediate attention from states and communities. The starting point should be the parents. First, coordinated policy efforts should be taken to provide employment and income support to all informal sector workers to stimulate the economy and labour demand. These measures will cushion enterprises and workers against immediate employment and income losses and reduce the probability of children being made to enter the workforce. As a direct measure, states should prioritise efforts to continue education for all children, using all available technology. Financial support or relaxation of school fees and other related school expenses should be given to those children who wouldn't be able to return to school otherwise. Governments should also enact measures to ensure inclusion of children with disabilities. States can reach out to local NGOs working on children with disabilities and engage with them at every stage of the response. These measures will no doubt respond to the emergency needs that COVID-19 has generated and also ease the life of children directly or indirectly to some extent. However, it is clear that more needs to be done to prevent children from lapsing into child labour.

Childhood has been imposing as a most important period of life. They are the prospering flowers of the garden of a society and valuable asset of a nation. During this situation child are details shape of the life and take place the behavior of attitudes are developed by the family. The predominance of child labour has seen in all periods of time, it varies in nature and size of depending on the current socioeconomic structure of the society. Whenever Child labour is generally required by economic forces of the parents. Their life is measured by low education, poor living standards, unethical 
working and living conditions, uncertainty of jobs, low income, long hours of work etc. Some reasons of child labour facing in different health impacts are adult workers, large families, and lack of educational facilities, illiteracy and ignorance of parents about the importance of education. It is unfortunate to say that tragically most of the child life is lost due to child work that main reasons are given to rise extensive of income, poverty and unemployment. It is clear that from this study child labor has higher likelihood to create negative impacts on future life. Since child worker does not get opportunity to get better education, they cannot get better job chances in future life.

\section{REFERENCES}

1. Dilip R. Khairnar (2017), Child Labour in Marathwada Region of India: Problems and Remedies, World Journal of Social Sciences and Humanities, Vol. 3, No. 2, pp.50-55.

2. Mridul Maheshwari Manjari Singh W.P (2008), Indian Institute of Management Ahmedabad India Research and Publications, January.

3. Sofya Krutikova (2009), Determinants of Child Labour: The Case of Andhra Pradesh First published by Young Lives in May 2009 () Young Lives 2009 ISBN: 978-1-904427-53-7.

4. Sumitra Sengupta, Shovan Ghosh(2013), "Poverty Child Labour and Access of Schooling in India Finding the gaps, Journal of Asian Research Consortium, Volume 3, Issue 1,January,ISSN 2249-7315.

5. Tripathy, S.K. (1989), Child Labour in India, Discovery Publishing House, New Delhi.

6. www.labor.state.ny.us

7. www.ilo.org

8. www.who.int

9. http://unicef.org 